\title{
The incretins: a link between nutrients and well-being
}

\author{
Rémy Burcelin* \\ UMR 5018 CNRS-UPS and IFR 31, Rangueil Hospital, L1 Bldg, BP 84225 Toulouse 31432 cedex 4, France
}

\begin{abstract}
The glucoincretins, glucagon-like peptide-1 (GLP-1) and gastric inhibitory peptide (GIP), are intestinal peptides secreted in response to glucose or lipid intake. Data on isolated intestinal tissues, dietary treatments and knockout mice strongly suggest that GIP and GLP-1 secretion requires glucose and lipid metabolism by intestinal cells. However, incretin secretion can also be induced by non-digestible carbohydrates and involves the autonomic nervous system and endocrine factors such as GIP itself and cholecystokinin. The classical pharmacological approach and the recent use of knockout mice for the incretin receptors have shown that a remarkable feature of incretins is the ability to stimulate insulin secretion in the presence of hyperglycaemia only, hence avoiding any hypoglycaemic episode. This important role is the basis of ongoing clinical trials using GLP-1 analogues. Since most of the data concern GLP-1, we will focus on this incretin. In addition, GLP-1 is involved in glucose sensing by the autonomic nervous system of the hepato-portal vein controlling muscle glucose utilization and indirectly insulin secretion. GLP-1 has been shown to decrease glucagon secretion, food intake and gastric emptying, preventing excessive hyperglycaemia and overfeeding. Another remarkable feature of GLP-1 is its secretion by the brain. Recently, elegant data showed that cerebral GLP-1 is involved in cognition and memory. Experiments using knockout mice suggest that the lack of the GIP receptor prevents diet-induced obesity. Consequently, macronutrients controlling intestinal glucose and lipid metabolism would control incretin secretion and would consequently be beneficial for health. The control of incretin secretion represents a major goal for new therapeutic as well as nutrition strategies for treating and/or reducing the risk of hyperglycaemic syndromes, excessive body weight and thus improvement of well-being.
\end{abstract}

Diabetes: Insulin secretion: Incretins: Inulin-type fructans

At the beginning of the 20th century and already 20 years before the discovery of insulin by Banting \& Best (1922), Bayliss \& Starling (1902) and Moore et al. (1906) showed that gut extract could control carbohydrate metabolism via the pancreas in response to factors arising from the intestine which could be used for the treatment of diabetes. In the late 1960s it was further demonstrated that an oral glucose load induced a higher insulin secretion than intravenously administered glucose while blood glucose levels were similar between the two modes of delivery, suggesting that glucose clearance was different and involved different mechanisms (Fig. 1; Perley \& Kpnis, 1967). These authors importantly showed the relevance of the underlying mechanism in diabetic subjects which led to the concept of incretins (Creutzfeldt, 1979), i.e. factors secreted by the intestine in response to an oral load of glucose or lipid that increase glucose-stimulated insulin secretion. This important discovery was followed by the identification and the characterization of intestinal peptides. First, in the 1970s, the gastric inhibitory peptide (GIP) was uncovered by Brown and Pedersen as being part of the incretin effect (Brown \& Pederson, 1970; Brown, 1971). Ten years later it was evident that another intestinal peptide, the glucagon-like peptide-1 (GLP-1), also participated in the incretin effect (Holst, 1977; Ebert \& Creutzfeldt, 1982; Ebert et al. 1983; Holst et al. 1987).

GLP-1 has been named upon sequence analysis of the proglucagon gene, which showed that this intestinal peptide has a high degree of homology with pancreatic glucagon (Bell et al. 1983). Interestingly, the coding sequence of a second GLP, named GLP-2, was also present on the same gene (Fig. 2). The precursor peptide containing all three hormones was named the pre-proglucagon or 'big glucagon'. The corresponding gene is expressed in the intestine (L cells), the pancreatic islets $(\alpha$-cells) and in the brain (Drucker, 1990; Creutzfeldt, 1992; Thorens \& Waeber, 1993; Holst, 1997; Blazquez et al. 1998; Nauck, 1998; Goldstone et al. 2000). The tissue-specific release of intestinal GLP and pancreatic glucagon is due to the combined action of pro-convertases named PC1/3, PC2, furin and carboxypeptidases (Orskov et al. 1987; Rouille et al. 1994, 1995; Fig. 2). A remarkable feature of GLP-1 is to be entirely conserved among all mammalian species where the corresponding gene has been cloned.

The GIP is also produced as a propeptide but the corresponding gene codes for only one functional peptide, GIP (Moody et al. 1984; Takeda et al. 1987; Creutzfeldt, 1992).

The biological effects of incretins have mainly been focusing on the increased responsiveness to glucose of pancreatic $\beta$-cells for the secretion of insulin. A large number of review papers based on more than 800 manuscripts report mechanisms underlying incretin-stimulated insulin secretion. It is beyond the scope of this review to detail all these papers. It will rather focus on evidences showing that the incretins, and precisely GLP-1, could control glucose metabolism throughout the regulation of the autonomic nervous system. The data would be interpreted with regard to the putative role that the non-digestible oligosaccharides including inulin-type fructans may have on incretin's secretion and actions.

\section{Regulation of glucoincretin secretion}

The L cells secreting GLP-1 are largely distributed in the lower gut ileum, colon and even rectum (Holst, 1994; Orskov et al. 
(A)

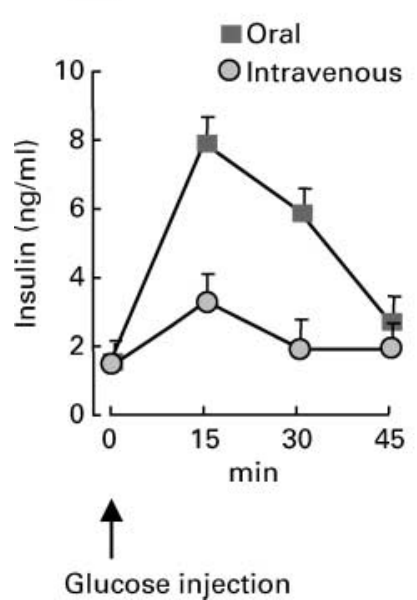

(B)

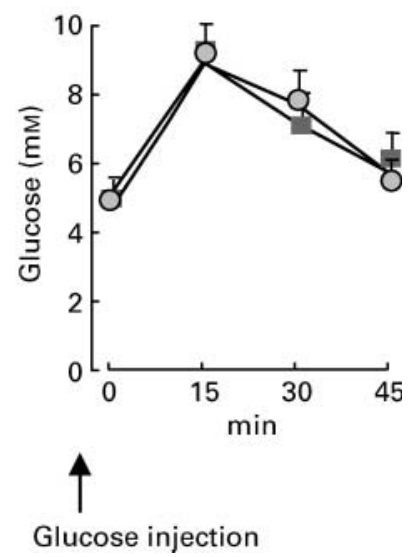

Fig. 1. Oral glucose absorption induced higher plasma insulin levels than intravenous glucose injection. (A) Plasma insulin and (B) plasma glucose concentrations in mice injected with glucose orally or intravenously (personal data). The data show that while the glycaemic levels were similar in both groups of mice, the plasma insulin concentration was dramatically higher in the mice receiving glucose orally. This effect is attributed to the incretins glucagon-like peptide- 1 and gastric inhibitory peptide being secreted by the intestine in response to oral glucose only.

1994). The biologically active GLP-1 is secreted as a 7-37 or 7-36 amide peptide while the $\mathrm{K}$ cells releasing GIP, as a 42 amino acid sequence, are present essentially in the duodenum (Buchan et al. 1978). However, both peptides are inactivated by an aminopeptidase, the dipeptidyl peptidase IV (DPPIV), which is produced in high amounts by intestinal epithelial cells (Deacon et al. 1995a). The enzyme removes the two first amino acids histidine-alanine leaving a totally inactive form of the circulating peptide (Fig. 2). Hence, the half-life of the biologically active GLP-1 is of the order of $30 \mathrm{~s}$. Consequently, a small fraction, less than $10 \%$, of the active peptide reaches the arterial blood stream to target the organs and an incretin gradient exists between the mesenteric/hepato-portal veins and the hepatic artery. The postprandial increase of incretin secretion is 5- to 10fold compared to the fasting levels. However, the amount of biologically active peptide in the systemic blood is much lower than the secreted amount (Orskov et al. 1994, 1996; Deacon et al. 1995b; Herrmann et al. 1995; Rocca \& Brubaker, 1995; Schirra et al. 1996). This already suggests that, since they are mostly degraded as soon as they are produced, the incretins should have a local role, i.e. at the vicinity of the mesenteric veins or the portal vein. Moreover, modifying the half-life of incretins (e.g. via changes in nutrition) could have significant effects. For example, one could suggest that the known effect of inulin-type fructans on intestinal epithelial growth could originate from a change in the cell composition of the intestinal wall and hence of the relative proportion of the DPPIV expressing cells. Consequently, the secreted incretins would be more or less degraded. However, whether the rapid degradation of incretins is an important regulatory mechanism avoiding their excessive action remains to be determined. In addition, one could also speculate that small molecules issued from inulintype fructans fermentation by the intestinal flora could release

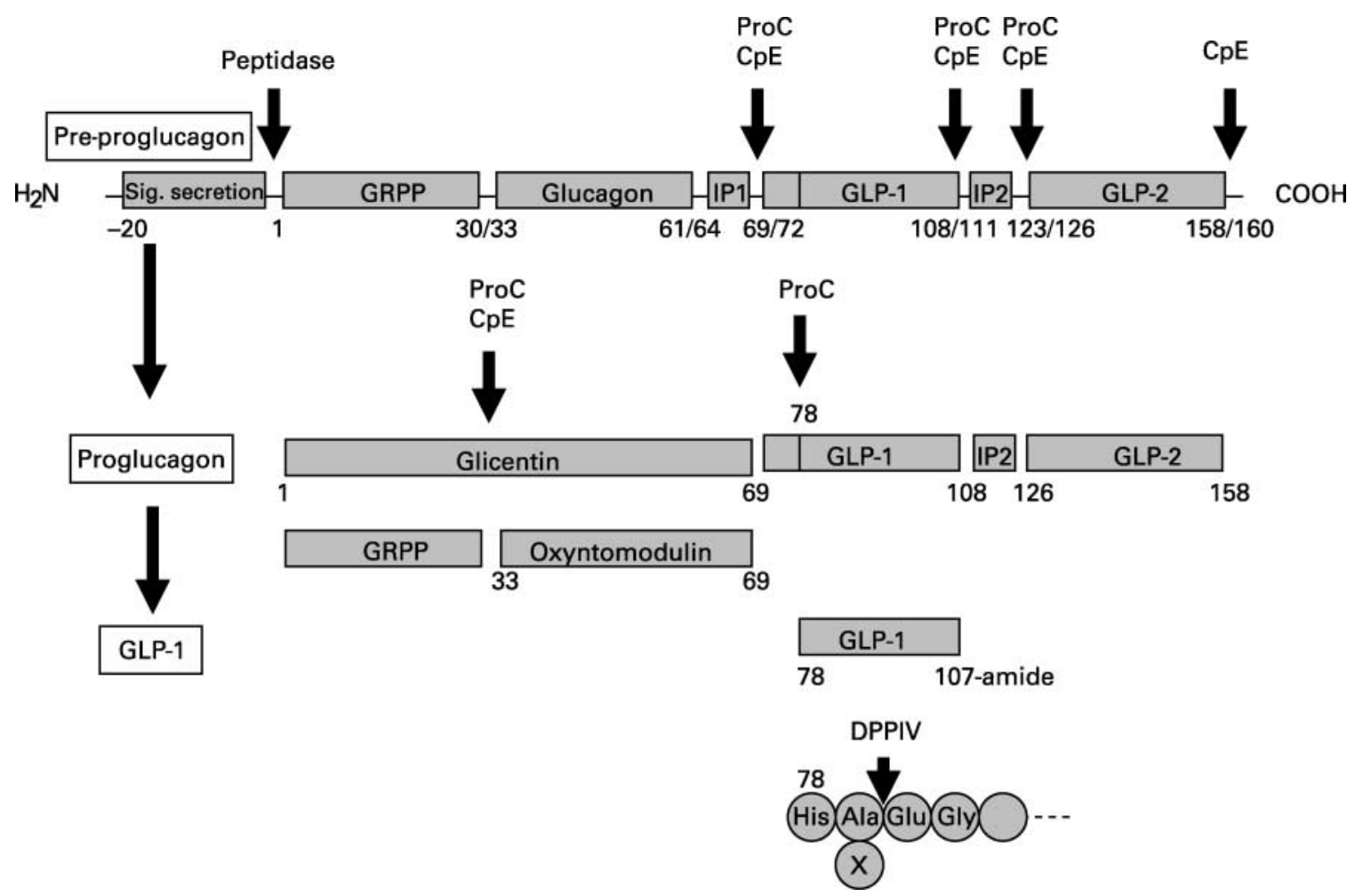

Fig. 2. Proglucagon processing leads to the secretion of glucagon-like peptide-1 (GLP-1) and other related peptides in intestinal $L$ cells. The pre-proglucagon peptide is composed of a signal peptide, a glicentin-related polypeptide (GRPP), glucagon, GLP-1, GLP-2, and intervening sequences (IP). The pre-proglucagon is first matured into proglucagon when a peptidase removes the signal peptide sequence. The proglucagon is then matured into GLP-1, GLP-2 and glicentin by the action of pro-convertases (ProC) and carboxypeptidases (CpE). The GLP-1 produced is then rapidly inactivated by the dipeptidyl peptidase IV (DPPIV) that removes the His-Ala residue in the $\mathrm{N}$-terminal. 
DPPIV inhibitors preventing the massive degradation of GLP-1 in the colon.

The incretin secretagogues are numerous, being nutrients, essentially carbohydrates and lipids (Knapper et al. 1995; Ritzel et al. 1997), hormones, cholecystokinin, GIP itself (Fukase et al. 1992; Roberge et al. 1996; Damholt et al. 1999), miscellaneous neur hormones and neuromediators (Ikeda et al. 1993; Balks et al. 1997). The most potent secretagogue seems to be a mix of fat and carbohydrate (Nordt et al. 1991; Knapper et al. 1995). While the metabolism of carbohydrate might be important for the secretion of GLP-1, it is not considered essential. Indeed, even though numerous carbohydrates including glucose, fructose and galactose induce GLP-1 secretion (Ritzel et al. 1997), whereas inhibitors of glucose metabolism such as 2-deoxyglucose and glucosamine inhibit GLP-1 secretion (Ritzel et al. 1997), still other data show that non-metabolized carbohydrate such as 3-O-methylglucose and methyl- $\alpha$-Dglucoside stimulates GLP-1 secretion (Ritzel et al. 1997). This last piece of evidence suggests that other carbohydrate-derived structures like non-digestible inulin-type fructans could control GLP-1 secretion through a mechanism not involving their fermentation. Whether receptors at the luminal side of the intestinal cells could be activated by inulin-type fructans remains to be determined. The secretion of GLP-1 is, however, dependent upon the integrity of the autonomic nervous system and essentially upon the signal sent by the vagus nerve (Nauck et al. 1996; Wettergren et al. 1997). In addition to nutrients, it has been shown, in a fetal rat intestinal cell model, that the secretion of glucagon-like immunoreactive peptides was stimulated by choleocystokinin-8 (Fehmann et al. 1990, 1991), a gastrin-releasing peptide, calcitonin gene-related peptide and by GIP, with GIP being the most potent factor at least in rodents (Brubaker, 1991). Similarly, in isolated rat intestinal tissues, the cholinergic agonist betanechol stimulated the secretion of GLP-1 while atropin inhibited the effect, revealing the role of the autonomic nervous system (Herrmann-Rinke et al. 1995). GLP-1 secretion was inhibited by somatostatin (Brubaker, 1991). In addition, the activation of neuroendocrine factors and of the parasympathetic nervous system during intestinal glucose delivery has been shown to stimulate GLP-1 secretion (Plaisancie et al. 1995; Plant \& Durrant, 1997; Rocca \& Brubaker, 1999).

\section{Effect of inulin-type fructans on secretion of glucagon-like peptide-1}

Few reports are available with regard to the role of inulin-type fructans on the control of incretin secretion. It has been reported that rats given a diet supplemented with $30 \%$ inulin-type fructans for 2 weeks had significantly increased plasma GLP-1 and insulin levels following an oral glucose load (Reimer \& McBurney, 1996; Kok et al. 1998a,b). Consequently, the glycaemic level of the rats was lower. In addition, GIP and GLP-1 concentrations were significantly higher in the serum of oligofructose-fed rats and the caecal GLP-1 pool was also higher. This latter data was related to an increased GLP-1 positive cell proliferation. Indeed, ileal proglucagon mRNA was increased, suggesting an additional trophic effect of inulin-type fructans on intestinal epithelial cells (Kok et al. 1998a). This effect was proportional to the amount of oligofructose in the diet. The improved glycaemic control could also be due to increased insulin sensitivity or through mechanisms independent of insulin action.

\section{Incretins stimulate insulin secretion}

Extended data show that incretins stimulate insulin secretion. After the cloning of the corresponding receptors, it was shown that the cellular mechanisms involve the intracellular increase of cAMP and Ca fluxes (Goke et al. 1989; Fridolf \& Ahrén, 1991, 1993; Gallwitz et al. 1993; Thorens \& Waeber, 1993; Thorens et al. 1993; van Eyll et al. 1994; Widmann et al. 1994; Holz et al. 1995; Volz et al. 1995). The cAMP activates protein kinase A that mediates numerous actions triggering the exocytosis of insulin. The most remarkable effect of incretins is the ability to stimulate insulin secretion only in the presence of glucose stimulatory concentrations increasing $\beta$-cell glucose responsiveness. The number of reports detailing this observation is too large to be uniformly cited and only major observations are referred to (Kreymann et al. 1987; Mojsov et al. 1987; Orskov et al. 1988, 1996; Shima et al. 1988; Nathan et al. 1991; Goke et al. 1993; Holz et al. 1993; Nauck et al. 1993a; Zawalich et al. 1993; Hargrove et al. 1995; Jehle et al. 1995; Kolligs et al. 1995; Qualmann et al. 1995; Volz et al. 1995; Wang et al. 1995; Zawalich \& Zawalich, 1996; Drucker, 1998; Ahrén \& Pacini, 1999; Tseng et al. 1999). Consequently, insulin secretion would stop when plasma glucose starts dropping below the physiological concentration of approximately $5 \mathrm{~mm}$, preventing the occurrence of iatrogenic hypoglycaemia. This characteristic makes incretins major candidates for the treatment of hyperglycaemic syndromes (Nauck et al. 1993c; Byrne \& Goke, 1996; Holst, 1996; Nauck, 1996; Willms et al. 1996; Ahrén et al. 1997; Goke et al. 1997; Burcelin et al. 1999; Juhl et al. 2000).

Another strategy to improve the glycaemic control of diabetic patients and which has been largely used is based upon the inhibition of DPPIV (Ahrén et al. 2000). One would suggest that due to the lack of specificity of the enzyme, the inhibitor might affect a large number of other neuropeptides. However, such secondary effects have not been reported and hence the strategy seems promising for the treatment of noninsulin dependent diabetes mellitus (NIDDM). No genetic association has been observed with mutations in the GLP-1 receptor (Tanizawa et al. 1994; Zhang et al. 1994), suggesting that compensatory mechanisms via the GIP secretion might exist. Hence, studies with double mutations on both incretin receptors should shed some light upon the important role of the intestinal hormones for the control of glucose metabolism.

The secretion profiles of incretins during diabetes and obesity have been reported but there are still discordant data. First reports showed that in twins with NIDDM, GLP-1 secretion was decreased during oral glucose ingestion (Vaag et al. 1996). However, the intensity of the diseases and the presence of family members with diabetes were associated with the impaired GLP-1 secretion. In this study GIP secretion was normal. In obese patients, it has been reported that secretion of both GIP and GLP-1 was excessive following an oral glucose load. This impairment was more pronounced in obese diabetic patients, suggesting that chronic hyperglycaemia would maintain high levels of incretin delaying the appearance of diabetes (Fukase et al. 1993). However, another report shows that GLP-1 secretion is preserved during diabetes, while GIP is reduced (Nauck et al. 1993b). The origin of these discrepancies is not yet understood but could be related to the multiplicity of the aetiology of diabetes. 


\section{Incretins regulate glucose homeostasis through non- $\beta$-cell mediated effects}

In addition to the effects of incretins on insulin secretion, the improved glycaemic control of GLP-1-treated NIDDM patients is associated with a glucagonostatic effect of the intestinal hormone. Indeed, glucagon secretion is reduced in hyperglycaemic patients when infused with GLP-1 (Orskov et al. 1988; Komatsu et al. 1989; Creutzfeldt et al. 1996). Similarly to insulin, the lowering of plasma glucagon level is stopped when glycaemia drops below normal levels. However, it is unclear whether GLP-1 receptors are present at the surface of the $\alpha$ pancreatic cells (Campos et al. 1994), which would suggest that the regulatory effect of incretins would be on other cells connected to the $\alpha$ pancreatic cells such as brain cells (Shimizu et al. 1987; Kanse et al. 1988; Uttenthal et al. 1992; Campos et al. 1994; Goke et al. 1995; Wei \& Mojsov, 1995; Alvarez et al. 1996). Indeed, the glucagon secretion is strongly dependent upon the autonomic nervous system (Rizza et al. 1979; Cryer, 1981; Gerich et al. 1990). Glucose sensors mostly located in the brain detect glycaemic variations and send a signal towards the pancreas to control glucagon secretion (Oomura et al. 1969, 1974; Oomura, 1981; Biggers et al. 1989; Frizzell et al. 1993). We recently showed that this message was dependent upon the expression of the extra-pancreatic glucose transporter GLUT2 (Burcelin \& Thorens, 2001).

The GLP-1 receptor has been described several times in cerebral cells (Shimizu et al. 1987; Kanse et al. 1988; Uttenthal et al. 1992; Campos et al. 1994; Goke et al. 1995; Wei \& Mojsov, 1995; Alvarez et al. 1996). Its functions have not been elucidated but could, at least in part, be associated with cognition and memory (During et al. 2003; Mattson et al. 2003). Indeed, when GLP-1 was administered into the cerebral ventricle of rats, the latency to a task was reduced as a matter of increased spatial learning. The co-infusion of exendin 9-39 completely blocked the effect of GLP-1. Interestingly, this effect was cholinergic-dependent since the injection of the cholinergic receptor agonist arecolin enhanced the effect of GLP-1. Similarly, the latency to learning of GLP-1 receptor knockout mice was increased when compared to control mice (During et al. 2003). Since hippocampus regions control the learning and memory mechanisms, this represents a target for memory-enhancing drug development. Such brain location expresses GLP-1 receptor and the reduced learning phenotype of the corresponding knockout mice could be rescued by the injection into the hippocampus of an adeno-associated virus expressing the GLP-1 receptor (During et al. 2003). Quantification by RT-PCR of GLP-1 receptor gene expression also shows that there is an up-regulation of the gene expression following training in an associative learning paradigm. The GLP-1 receptor knockout mice were also more sensitive to kainate administration induced seizure and neuronal injury (During et al. 2003), suggesting a neuroprotective effect of GLP-1. This new concept would be due to the stimulation of the brain hippocampus regions by the intestine-released hormone GLP-1. The subtlety of the interpretation resides in the fact that it is probably not the GLP-1 released from the intestine that triggers the hippocampus and increases learning but rather the GLP-1 released by some cerebral cells into the hippocampus that provides neural and social plasticity. Indeed, GLP-1 is present in the brain (Kreymann et al. 1989; Yoshimoto et al. 1989; Blazquez et al. 1998; Donahey et al. 1998; van Dijk \& Thiele, 1999; Goldstone et al. 2000; Gulpinar et al. 2000; Rodriquez de Fonseca et al. 2000). This incretin is mostly distributed in the brain stem nucleus such as the nucleus solitarius (Goldstone et al. 2000) and its distribution seems not to change during streptozotocin-induced diabetes. The GLP-1 receptor and the GLP-1 were mostly localized in the same nuclei and induced cAMP formation (Shimizu et al. 1987). GLP-1 in the brain has been proposed to control water and food intake (Turton et al. 1996; Furuse et al. 1997; Donahey et al. 1998; Gulpinar et al. 2000; Rodriquez de Fonseca et al. 2000) and taste aversion (Thiele et al. 1997). The intracerebroventricular injection of GLP-1 powerfully inhibits feeding in fasted rats (Turton et al. 1996). The injection of exendin 9-39 blocks the inhibitory effect of GLP-1 and potentiates the effect of orexigenic factors such as neuropeptide Y. To determine the cerebral structures involved, the authors have quantified c-fos as a marker of neuronal activation. Following GLP-1 injection, c-fos exclusively appeared in the paraventricular nucleus of the hypothalamus and the central nucleus of the amygdala. The labels were masked by the injection of exendin 9-39. In addition, leptin injection increased GLP-1 production in the brain stem (Goldstone et al. 2000); it was therefore suggested that part of the anorectic effect of leptin could be mediated via the release of GLP-1. Hence, inulin-type fructans activating the release of GLP-1 into the brain by stimulating the vagus nerve signal would enhance memory and cognition.

\section{Incretins control the autonomic nervous system}

During a meal, the intestine absorbs energetic nutrients, such as glucose and lipids. While lipids reach the lymphatic stream and are delivered to the systemic circulation, carbohydrates are delivered directly to the hepato-portal vein. A positive gradient of carbohydrate concentration between the hepato-portal vein and the arterial blood is thus established (Fig. 3). Glucose-sensitive units present in the hepato-portal vein detect this gradient (Niijima, 1969; Pagliassotti et al. 1991, 1996) and send a signal through the hepatic branch of the vagus nerve to target tissues such as the liver (Niijima, 1985; Gardemann et al. 1986; Moore \& Cherrington, 1996; Moore et al. 1996; Stumpel \& Jungermann, 1997), the hypothalamus (Schmitt, 1973; Shimizu et al. 1983), insulin-secreting $\beta$-cells (Berthoud et al. 1983), the brain stem (Adachi et al. 1984) and the adrenal glands (Hevener et al. 1997, 2000). The specific cellular functions that are activated then participate to the adaptation of the body to the new metabolic situation. We previously described that one of the consequences of activating the hepato-portal glucose sensor was to increase blood glucose clearance (Fig. 4) and utilization in a subset of tissues, mostly heart, soleus and brown adipose tissue (Burcelin et al. 2000b). The activation of whole body glucose clearance induced a paradoxical hypoglycaemic state (Fig. 4). We also showed that activation of this sensor was inhibited by somatostatin and that it required the presence of the glucose transporter GLUT2 (Burcelin et al. 2000a). Along the same line of investigation we infused GLP-1 and glucose into the portal vein of normal mice (Burcelin et al. 2001). The infusion of GLP-1 did not modify portal glucose sensitivity. In the presence or absence of portal GLP-1 infusion, plasma insulin levels and glucose clearance were similarly increased by glucose, suggesting that portal GLP-1 has no role on the nervous reflex stimulating insulin secretion and glucose clearance. However, when the same experiment was performed in GLP-1 receptor knockout mice, hyperglycaemia developed during the portal glucose infusion suggesting that the receptor was important (Fig. 5). We further identified the location where the 


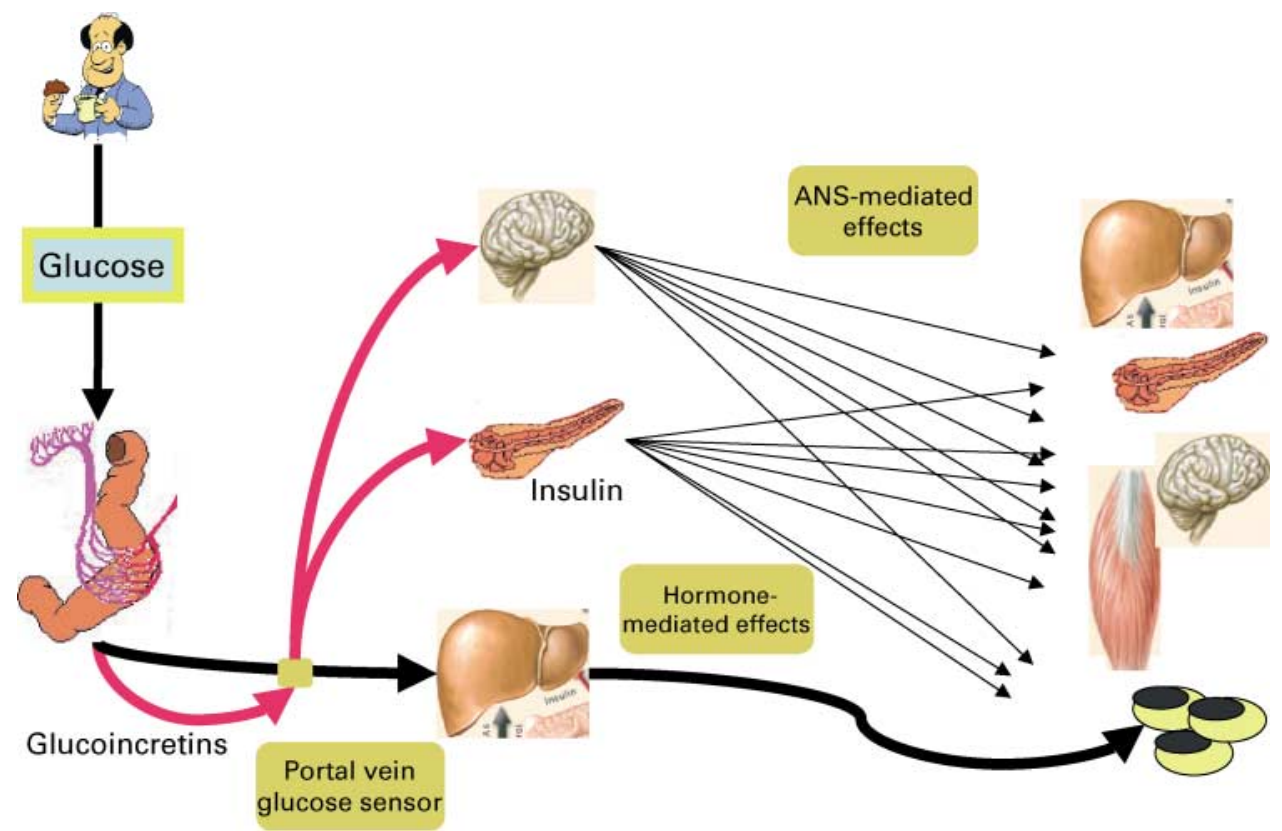

Fig. 3. Incretin-mediated effects. After oral glucose absorption, the incretins are released into the portal vein that then reach the systemic circulation and stimulate insulin secretion. In addition, glucose is absorbed and accumulates into the hepato-portal vein. A glucose sensor detects the glycaemic variations and sends a signal mediated by the autonomic nervous system (ANS) to the peripheral tissues. The glucagon-like protein-1 receptor in the hepato-portal sensor is necessary for the transmission of the glucose signal towards peripheral tissues. Consequently, hepatic glucose production, muscle glucose utilization, insulin and glucagon secretions, memory and cognitive functions are controlled by endocrine and neural routes both dependent upon the release of incretins.

GLP-1 receptor was important by infusing the inverse agonist exendin 9-39 via different routes. No effects were detected when the exendin 9-39 was infused into the systemic circulation (i.e. through the femoral vein). However, when the peptide was infused along with glucose into the portal vein, hyperglycaemia rather than hypoglycaemia developed suggesting that, in the portal vein, the GLP-1 receptor provided the sensitivity to glucose (Fig. 5). During the portal glucose infusion, plasma insulin did also increase. Few reports suggest that sensory nerves could contribute to insulin secretion via an indirect route involving the enteric autonomic

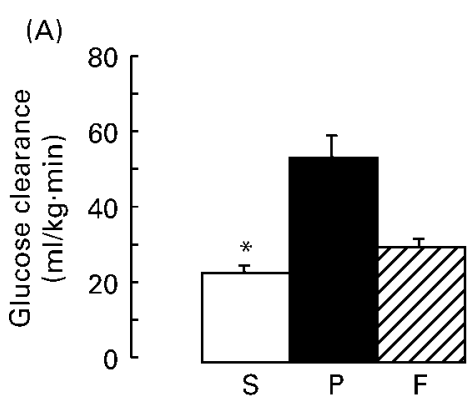

(B)

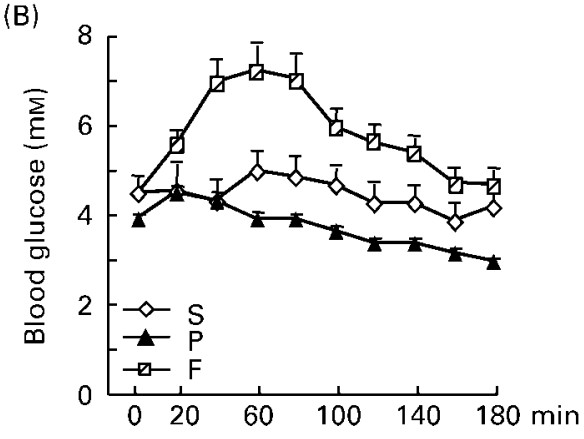

(C)

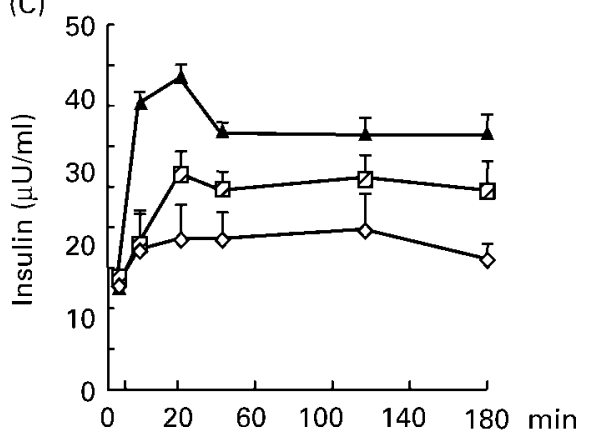

Fig. 4. Portal glucose infusion increased glucose clearance and induced a paradoxical hypoglycaemic state. Glucose or saline (S) was infused at a low rate into the hepato-portal vein $(P)$ to activate the corresponding sensor or into the femoral vein $(F)$ as a negative control. (A) Glucose clearance was increased in mice infused with glucose into the portal vein, while only a small effect was observed in the femoral infused mice. (B) The portal glucose infusion but not the femoral glucose infusion induced hypoglycaemia. (C) Plasma insulin levels were increased by the portal glucose infusion despite hypoglycaemia, suggesting a reflex activated by the portal glucose sensor and independent of the peripheral glycaemic level. Plasma insulin concentration rose in the blood of femoral infused mice as a consequence of hyperglycaemia. Adapted from Burcelin et al. (2000b) 


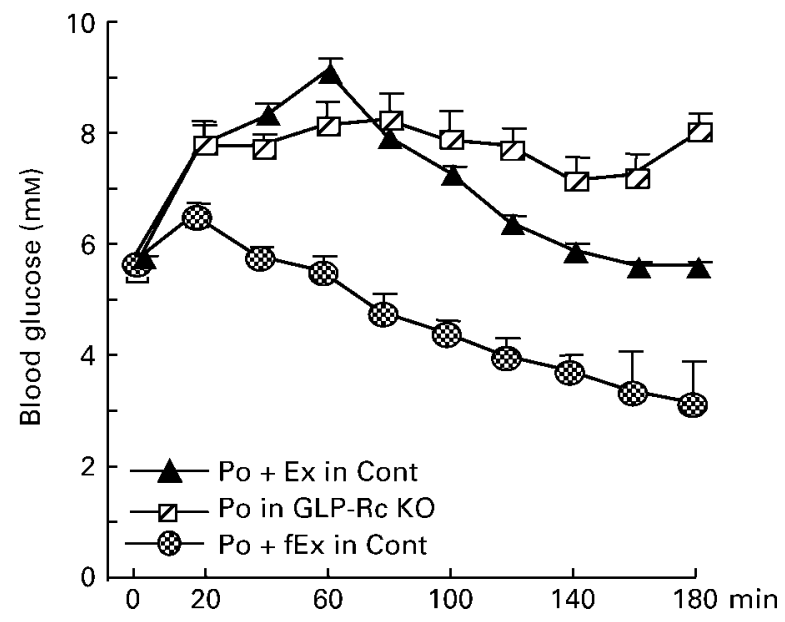

Fig. 5. The glucagon-like protein-1 (GLP-1) receptor is required for hepatoportal vein glucose sensing. GLP-1 receptor knockout mice were infused with glucose into the portal vein (Po in GLP-1 Rc KO). In these animals hyperglycaemia rather than hypoglycaemia developed, suggesting a role of the GLP-1 receptor in the maintenance of glucose responsiveness. In control mice glucose was infused in the presence of exendin 9-39 (the inverse agonist of the GLP-1 receptor) into the portal vein (Po + Ex in Cont) or into the femoral vein (Po $+\mathrm{fEx}$ in Cont). Hyperglycaemia developed with exendin 9-39 when infused with glucose into the portal vein but not into the femoral vein, denoting that the GLP-1 receptor in the portal vein was important to maintain the glucose responsiveness of the sensor.

nervous system. It has been demonstrated that the augmentation of glucose-stimulated insulin secretion induced by intraportal administration of GLP-1 is abolished by a ganglion blocker in rats (Balkan \& Li, 2000). Moreover, the intraportal administration of GLP-1 activates electrical activity in hepatic afferents in rats (Nakabayashi et al. 1996). It is suggested that GLP-1 may activate afferent nerve endings that, through a neural effect, stimulate insulin secretion elicited by the autonomic nervous system innervating the islets. To test such hypothesis, it has been reported that the permanent sensory inactivation by neonatal capsaicin injection blunted the indirect stimulation of glucose-induced insulin secretion (Ahrén, 2004). Similarly, we analysed insulin secretion in GLP-1 receptor knockout mice in response to oral or intraperitoneal glucose load. The data showed that insulin secretion, 2 min after the oral glucose load, was increased in control mice but strongly reduced in mutant mice (Fig. 6). At this time point the mice were still euglycaemic. The early insulin peak of secretion was not observed in GIP receptor knockout mice, suggesting that the neural control of the regulatory loop was restricted to the action of GLP-1 on the autonomic nervous system. This is in agreement with the very short half-life of GLP-1 and its release site, i.e. the hepato-portal vein.

Another enteric born-regulatory loop is the inhibition of gastric emptying. Human studies show that, when glucose was given orally, gastric emptying was activated and that the emptying of glucose was controlled by the release of GLP-1. This indeed suggests that, while gastric emptying is controlled by GLP-1, the hormone secretion is also controlled by gastric emptying allowing the persistence of glucose into the gut and hence the secretion of more GLP-1. This regulatory loop was, however, not observed for GIP (Schirra et al. 1996). Gastric emptying has been assessed in diabetic patients showing that GLP-1 inhibits gastric emptying together with the stimulation of insulin and the inhibition of glucagon secretion. These effects probably contribute to the blood glucose-lowering action of GLP-1 when studied after meal ingestion (Willms et al. 1996; Young et al. 1996). The role of GLP-1 in the control of gastric emptying, is dependent upon the integrity of the vagus nerve. Indeed, the vagal afferent enervation and the peripheral administration of exendin 9-39 enhanced gastric emptying, suggesting a motor role of the vagus nerve. This was confirmed by the cerebral
(A)

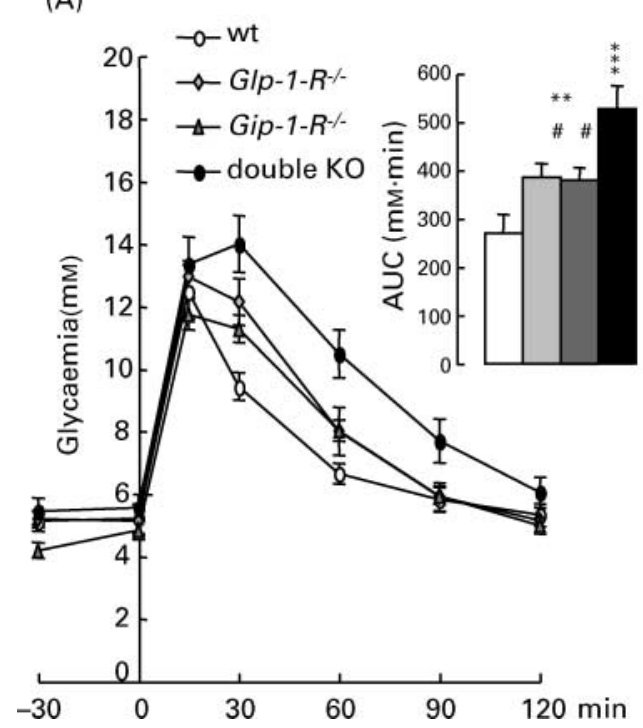

(B)

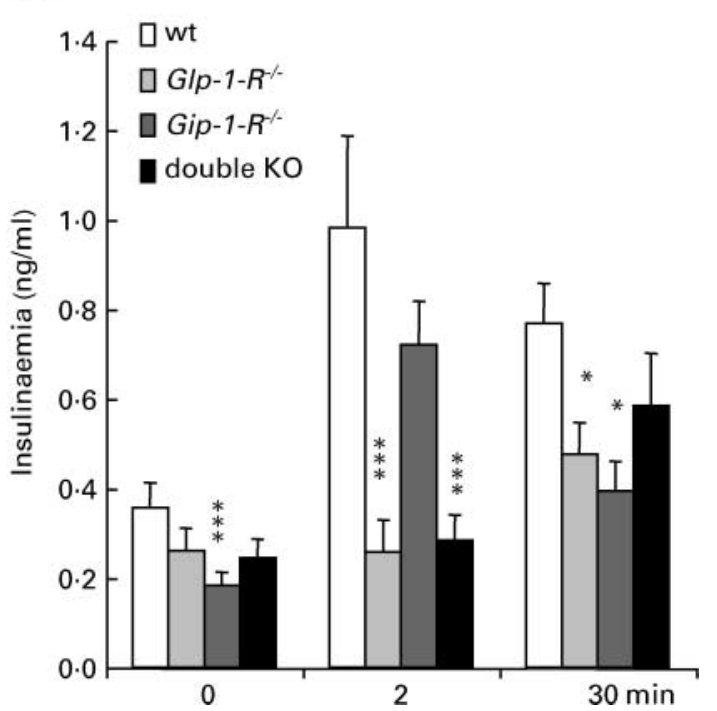

Fig. 6. The glucagon-like protein-1 (GLP-1) receptor is necessary for the early stimulation of insulin secretion during oral glucose absorption. Mice underwent an oral glucose injection and plasma insulin levels were assessed 2 and 30 min later. The figure shows that the GLP-1 receptor and gastric inhibitory peptide (GIP) receptor knockout mice are glucose-intolerant and that the double mutant is even more glucose-intolerant. Insulin secretion was not induced after 2 min in the absence of the GLP-1 receptor only, showing the GLP-1-dependent regulatory reflex. The GIP receptor was not involved in this process. In addition, plasma insulin concentration was reduced after $30 \mathrm{~min}$ in all mutant mice showing the role of the incretin receptor at the level of the $\beta$-cell. The inset of (A) shows the area under the curve (AUC) of the glucose tolerance test. 
injection of GLP-1 which could delay gastric emptying while no effect was observed when the vagal nerve was cut earlier (Imeryuz et al. 1997).

\section{Lessons from genetically engineered mice}

The incretin receptors have been knocked out in the mouse. The first study on the GLP-1 receptor knockout reported that the mice developed normally, but exhibited increased levels of blood glucose following oral glucose challenge (Scrocchi et al. 1996). This was associated with a reduced circulating insulin level. The intracerebroventricular administration of GLP-1 did not produce its satiating effect in the mutant mice, but no difference in body weight or feeding behaviour was noticed. Similarly, mice with a targeted mutation of the GIP receptor have higher blood glucose and impaired initial insulin response after oral glucose load although glycaemia was normal after a meal (Miyawaki et al. 1999). When fed a high-fat diet, the knockout mice were still normoglycaemic but with dramatically increased insulin secretion as a compensatory mechanism. The GIP receptor is more widely expressed in the body than the GLP-1 receptor. Noteworthy, it is expressed in adipose tissue, which is now considered as an important regulator of glucose homeostasis. In addition to the action of incretin on insulin secretion, the present study shows that the use of mutant mice for the corresponding receptors has uncovered the major role of GLP-1 in the activation of extra-pancreatic glucose sensors for the control of glucose metabolism. However, due to the multicellular distribution of the incretin receptors, tissue-specific deletion would nail down the role of each receptor for the control of nutritional homeostasis.

\section{Conclusion}

The secretion of incretins in response to nutrients leads to:

(1) the control of pancreatic insulin and glucagon secretions;

(2) the maintenance of extra-pancreatic glucose sensitivity;

(3) the regulation of gastric emptying and food intake;

(4) the maintenance of cognitive functions and memory.

Consequently, all these effects are major regulators of glucose and lipid homeostasis affecting secondarily body weight. Whether nutrients like inulin-type fructans can positively interfere with the incretin system remains to be assessed using appropriate analyses in adapted animal models of nutritional diseases and genetically engineered mice to bring out the molecular bases of the action of inulin-type fructans on digestive functions.

\section{References}

Adachi A, Shimizu N, Oomura Y \& Kobashi M (1984) Convergence of hepatoportal glucose-sensitive afferent signals to glucose-sensitive units within the nucleus of the solitary tract. Neurosci Lett 46 $215-218$.

Ahrén B (2004) Sensory nerves contribute to insulin secretion by glucagon-like peptide-1 in mice. Am J Physiol Regul Integr Comp Physiol 286, R269-R272.

Ahrén B \& Pacini G (1999) Dose-related effects of GLP-1 on insulin secretion, insulin sensitivity, and glucose effectiveness in mice. Am J Physiol 277, E996-E1004.

Ahrén B, Larsson H \& Holst JJ (1997) Effects of glucagon-like peptide-1 on islet function and insulin sensitivity in noninsulin-dependent diabetes mellitus. J Clin Endocrinol Metab 82, 473-478.

Ahrén B, Holst J, Martensson H \& Balkan B (2000) Improved glucose tolerance and insulin secretion by inhibition of dipeptidyl peptidase IV in mice. Eur $J$ Pharmacol 404, 239-245.

Alvarez E, Roncero I, Chowen JA, Thorens B \& Blazquez E (1996) Expression of the glucagon-like peptide-1 receptor gene in rat brain. J Neurochem 66, 920-927.

Balkan B \& Li X (2000) Portal GLP1 administration in rats augments the insulin response to glucose via neuronal mechanisms. Am J Physiol 279, R1449-R1454.

Balks HJ, Holst JJ, von zur Muhlen A \& Brabant G (1997) Rapid oscillations in plasma glucagon-like peptide-1 (GLP-1) in humans: cholinergic control of GLP-1 secretion via muscarinic receptors. $J$ Clin Endocrinol Metab 82, 786-790.

Banting FG \& Best CH (1922) The internal secretion of the pancreas. J Lab Clin Med 7, 251-266.

Bayliss WM \& Starling EH (1902) The mechanisms of pancreatic secretion. J Physiol 22, 325-330.

Bell G, Sanchez-Pescador R, Laybourn P \& Najarian R (1983) Exon duplication and divergence in the human preproglucagon gene. Nature 304, 368-371.

Berthoud HR, Niijima A, Sauter JF \& Jeanrenaud B (1983) Evidence for a role of the gastric, coeliac and hepatic branches in vagally stimulated insulin secretion in the rat. J Auton Nerv Syst 7, 97-110.

Biggers DW, Myers SR, Neal D, Stinson R, Cooper NB, Jaspan JB, Williams PE, Cherrington AD \& Frizzell RT (1989) Role of brain in counterregulation of insulin-induced hypoglycemia in dogs. Diabetes $\mathbf{3 8}$, 7-16.

Blazquez E, Alvarez E, Navarro M, Roncero I, Rodriguez-Fonseca F, Chowen JA \& Zueco JA (1998) Glucagon-like peptide-1 (7-36) amide as a novel neuropeptide. Mol Neurobiol 18, 157-173.

Brown JC (1971) A gastric inhibitory peptide. I. The amino acid composition and the tryptic peptides. Can J Biochem 49, 255-261.

Brown JC \& Pederson R (1970) A multiparameter study on the action of preparations containing cholecystokinin pancreozymin. Scand J Gastroenterol 5, 537-541.

Brubaker PL (1991) Regulation of intestinal proglucagon-derived peptide secretion by intestinal regulatory peptides. Endocrinology 128, 3175-3182.

Buchan A, Polak J, Capella C, Solcia E \& Pearse A (1978) Electron immunocytochemical evidence for the K-cell. Localization of gastric inhibitory polypeptide (GIP) in man. Histochemistry 56, 37-44.

Burcelin R \& Thorens B (2001) Evidence that extrapancreatic GLUT2dependent glucose sensors control glucagon secretion. Diabetes 50, 1282-1289.

Burcelin R, Rolland E, Dolci W, Germain S, Carrel V \& Thorens B (1999) Encapsulated, genetically engineered cells, secreting glucagon-like peptide-1 for the treatment of non-insulin-dependent diabetes mellitus. Ann NY Acad Sci 875, 277-285.

Burcelin R, Dolci W \& Thorens B (2000a) Glucose sensing by the hepatoportal sensor is GLUT-2 dependent; in vivo analysis in GLUT-2 null mice. Diabetes 49, 1643-1648.

Burcelin R, Dolci W \& Thorens B (2000b) Portal glucose infusion in the mouse induces hypoglycemia. Evidence that the hepatoportal glucose sensor stimulates glucose utilization. Diabetes 49, 1635-1642.

Burcelin R, Da Costa A, Drucker D \& Thorens B (2001) Glucose competence of the hepatoportal vein sensor requires the presence of an activated glucagon-like peptide-1 receptor. Diabetes 50, 1720-1728.

Byrne MM \& Goke B (1996) Human studies with glucagon-like-peptide1: potential of the gut hormone for clinical use. Diabet Med 13, $854-860$.

Campos RV, Lee YC \& Drucker DJ (1994) Divergent tissue-specific and developmental expression of receptors for glucagon and glucagon-like peptide-1 in the mouse. Endocrinology 134, 2156-2164.

Creutzfeldt W (1979) The incretin concept today. Diabetologia 16, $75-85$. 
Creutzfeldt W (1992) Entero-insular axis and diabetes mellitus. Horm Metab Res Suppl, 26, 13-18.

Creutzfeldt WO, Kleine N, Willms B, Orskov C, Holst JJ \& Nauck MA (1996) Glucagonostatic actions and reduction of fasting hyperglycemia by exogenous glucagon-like peptide $\mathrm{I}(7-36)$ amide in type I diabetic patients. Diabetes Care 19, 580-586.

Cryer P (1981) Glucose counterregulation in man. Diabetes 30, 261-264.

Damholt A, Kofod H \& Buchan A (1999) Immunocytochemical evidence for a paracrine interaction between GIP and GLP-1-producing cells in canine small intestine. Cell Tissue Res 298, 287-293.

Deacon CF, Johnsen AH \& Holst JJ (1995a) Degradation of glucagon-like peptide- 1 by human plasma in vitro yields an N-terminally truncated peptide that is a major endogenous metabolite in vivo. J Clin Endocrinol Metab 80, 952-957.

Deacon CF, Nauck MA, Toft-Nielsen M, Pridal L, Willms B \& Holst JJ (1995b) Both subcutaneously and intravenously administered glucagon-like peptide I are rapidly degraded from the NH2-terminus in type II diabetic patients and in healthy subjects. Diabetes 44, 1126-1131.

Donahey J, Van Dijk G, Woods S \& Seeley R (1998) Intraventricular GLP-1 reduced short but not long term food intake or body weight in lean and obese rats. Brain Res 779, 75-83.

Drucker DJ (1990) Glucagon and the glucagon-like peptides. Pancreas 5, 484-488.

Drucker DJ (1998) Glucagon-like peptides. Diabetes 47, 159-169.

During M, Cao L \& Zuzga D, et al. (2003) Glucagon like peptide 1 receptor is involved in learning and neuroprotection. Nat Med 9, 1173-1179.

Ebert R \& Creutzfeldt W (1982) Influence of gastric inhibitory polypeptide antiserum on glucose induced insulin secretion in rats. Endocrinology 111, 1601-1606.

Ebert R, Unger H \& Creutzfeldt W (1983) Preservation of incretin activity after removal of gastric inhibitory polypeptide (GIP) from rat gut extracts by immunoadsorption. Diabetologia 24, 449-454.

Fehmann HC, Goke B, Weber V, Goke R, Trautmann ME, Richter G \& Arnold R (1990) Interaction of glucagon-like peptide-1 (7-36) amide and cholecystokinin- 8 in the endocrine and exocrine rat pancreas. Pancreas 5, 361-365.

Fehmann HC, Goke R, Goke B, Bachle R, Wagner B \& Arnold R (1991) Priming effect of glucagon-like peptide-1 (7-36) amide, glucosedependent insulinotropic polypeptide and cholecystokinin- 8 at the isolated perfused rat pancreas. Biochim Biophys Acta 1091, 356-363.

Fridolf T \& Ahren B (1991) GLP-1(7-36) amide stimulates insulin secretion in rat islets: studies on the mode of action. Diabetes Res 16, 185-191.

Fridolf T \& Ahren B (1993) Effects of glucagon like peptide-1(7-36) amide on the cytoplasmic $\mathrm{Ca}(2+)$-concentration in rat islet cells. $\mathrm{Mol}$ Cell Endocrinol 96, 85-90.

Frizzell RT, Jones EM, Davis SN, Biggers DW, Myers SR, Connolly CC, Neal DW, Jaspan JB \& Cherrington AD (1993) Counterregulation during hypoglycemia is directed by widespread brain regions. Diabetes 42, 1253-1261.

Fukase N, Takahashi H, Manaka H, Igarashi M, Yamatani K, Daimon M, Sugiyama K, Tominaga M \& Sasaki H (1992) Differences in glucagonlike peptide-1 and GIP responses following sucrose ingestion. Diabetes Res Clin Pract 15, 187-195.

Fukase N, Igarashi M, Takahashi H, Manaka H, Yamatani K, Daimon M, Tominaga M \& Sasaki H (1993) Hypersecretion of truncated glucagonlike peptide-1 and gastric inhibitory polypeptide in obese patients. Diabet Med 10, 44-49.

Furuse M, Matsumoto M, Okumura J, Sugahara K \& Hasegawa S (1997) Intracerebroventricular injection of mammalian and chicken glucagonlike peptide- 1 inhibits food intake of the neonatal chick. Brain Res $\mathbf{7 5 5}$, $167-169$.

Gallwitz B, Witt M, Folsch UR, Creutzfeldt W \& Schmidt WE (1993) Binding specificity and signal transduction of receptors for glucagonlike peptide-1(7-36)amide and gastric inhibitory polypeptide on RINm5F insulinoma cells. $J$ Mol Endocrinol 10, 259-268.

Gardemann A, Strulik H \& Jungermann K (1986) A portal-arterial glucose concentration gradient as a signal for an insulin-dependent net glucose uptake in perfused rat liver. FEBS Lett 202, 255-259.

Gerich J, Cryer P \& Rizza R (1990) Hormonal mechanisms in acute glucose counterregulation: the relative role of glucagon, epinephrine, norepinephrine, growth hormone, and cortisol. Metabolism 29, 1164-1175.

Goke B, Fehmann HC, Schirra J, Hareter A \& Goke R (1997) The intestinal hormone glucagon-like peptide 1 (GLP-1): from experiment to the clinic. Z Gastroenterol 35, 285-294.

Goke R, Trautmann ME, Haus E, Richter G, Fehmann HC, Arnold R \& Goke B (1989) Signal transmission after GLP-1(7-36)amide binding in RINm5F cells. Am J Physiol 257, G397-G401.

Goke R, Wagner B, Fehmann HC \& Goke B (1993) Glucose-dependency of the insulin stimulatory effect of glucagon-like peptide-1 (7-36) amide on the rat pancreas. Res Exp Med 193, 97-103.

Goke R, Larsen PJ, Mikkelsen JD \& Sheikh SP (1995) Distribution of GLP-1 binding sites in the rat brain: evidence that exendin-4 is a ligand of brain GLP-1 binding sites. Eur J Neurosci 7, 2294-2300.

Goldstone AP, Morgan I, Mercer JG, Morgan DG, Moar KM, Ghatei MA \& Bloom SR (2000) Effect of leptin on hypothalamic GLP-1 peptide and brain-stem pre-proglucagon mRNA. Biochem Biophys Res Commun 269, 331-335.

Gulpinar MA, Bozkurt A, Coskun T, Ulusoy NB \& Yegen BC (2000) Glucagon-like peptide (GLP-1) is involved in the central modulation of fecal output in rats. Am J Physiol Gastrointest Liver Physiol 278, G924-G929.

Hargrove DM, Nardone NA, Persson LM, Parker JC \& Stevenson RW (1995) Glucose-dependent action of glucagon-like peptide-1 (7-37) in vivo during short- or long-term administration. Metabolism 44, $1231-1237$.

Herrmann C, Goke R, Richter G, Fehmann HC, Arnold R \& Goke B (1995) Glucagon-like peptide-1 and glucose-dependent insulin-releasing polypeptide plasma levels in response to nutrients. Digestion 56, 117-126.

Herrmann-Rinke C, Voge A, Hess M \& Goke B (1995) Regulation of glucagon-like peptide-1 secretion from rat ileum by neurotransmitters and peptides. $J$ Endocrinol 147, 25-31.

Hevener AL, Bergman RN \& Donovan CM (1997) Novel glucosensor for hypoglycemic detection localized to the portal vein. Diabetes $\mathbf{4 6}$, $1521-1525$.

Hevener AL, Bergman RN \& Donovan CM (2000) Portal vein afferents are critical for the sympathoadrenal response to hypoglycemia. Diabetes 49, 8-12.

Holst JJ (1977) Extraction, gel filtration pattern, and receptor binding of porcine gastrointestinal glucagon-like immunoreactivity. Diabetologia 13, 159-169.

Holst JJ (1994) Glucagon like peptide 1: a newly discovered gastrointestinal hormone. Gastroenterology 107, 1848-1855.

Holst JJ (1996) GLP-1 in NIDDM. Diabet Med 13, S156-S160.

Holst JJ (1997) Enteroglucagon. Annu Rev Physiol 59, 257-271.

Holst JJ, Orskov C, Nielsen OV \& Schwartz TW (1987) Truncated glucagon-like peptide I, an insulin-releasing hormone from the distal gut. FEBS Lett 211, 169-174.

Holz GGt, Kuhtreiber WM \& Habener JF (1993) Pancreatic beta-cells are rendered glucose-competent by the insulinotropic hormone glucagonlike peptide-1(7-37). Nature 361, 362-365.

Holz GGt, Leech CA \& Habener JF (1995) Activation of a cAMP-regulated $\mathrm{Ca}(2+)$-signaling pathway in pancreatic beta-cells by the insulinotropic hormone glucagon-like peptide-1. J Biol Chem 270, 17749-17757.

Ikeda T, Ochi H, Ohtani I, Fujiyama K, Hoshino T, Tanaka Y, Takeuchi T \& Mashiba H (1993) Possible role of the adrenergic mechanism in gastric inhibitory polypeptide- and glucagon-like peptide-1 (7-36) amide-induced insulin release in the rat. Metabolism 42, 209-213.

Imeryuz N, Yegen BC, Bozkurt A, Coskun T, Villanueva-Penacarrillo ML \& Ulusoy NB (1997) Glucagon-like peptide-1 inhibits gastric emptying via vagal afferent-mediated central mechanisms. Am J Physiol 273, G920-G927.

Jehle PM, Jehle D, Fussganger RD \& Adler G (1995) Effects of glucagonlike peptide-1 (GLP-1) in RINm5F insulinoma cells. Stimulation 
of insulin secretion, insulin content, and insulin receptor binding. Exp Clin Endocrinol Diabetes 2, 31-36.

Juhl C, Schmitz O, Pincu S, Holdt J, Veldhuis J \& Porksen N (2000) Short-term treatment with GLP-1 increases pulsatile insulin secretion in type II diabetes with no effect on orderliness. Diabetologia 43, 583-588.

Kanse SM, Kreymann B, Ghatei MA \& Bloom SR (1988) Identification and characterization of glucagon-like peptide-1 7-36 amide-binding sites in the rat brain and lung. FEBS Lett 241, 209-212.

Knapper JM, Heath A, Fletcher JM, Morgan LM \& Marks V (1995) GIP and GLP-1(7-36)amide secretion in response to intraduodenal infusions of nutrients in pigs. Comp Biochem Physiol C Pharmacol Toxicol Endocrinol 111, 445-450.

Kok NN, Morgan LM, Williams CM, Roberfroid MB, Thissen JP \& Delzenne NM (1998a) Insulin, glucagon-like peptide 1, glucose-dependent insulinotropic polypeptide and insulin-like growth factor I as putative mediators of the hypolipidemic effect of oligofructose in rats. J Nutr 128, 1099-1103.

Kok NN, Taper HS \& Delzenne NM (1998b) Oligofructose modulates lipid metabolism alterations induced by a fat-rich diet in rats. $J$ Appl Toxicol 18, 47-53.

Kolligs F, Fehmann HC, Goke R \& Goke B (1995) Reduction of the incretin effect in rats by the glucagon-like peptide 1 receptor antagonist exendin (9-39) amide. Diabetes 44, 16-19.

Komatsu R, Matsuyama T \& Namba M (1989) Glucagonostatic and insulinotropic action of glucagon like peptide-1-(7-36)-amide. Diabetes 38, 902-905.

Kreymann B, Williams G, Ghatei MA \& Bloom SR (1987) Glucagon-like peptide-1 7-36: a physiological incretin in man. Lancet 2, 1300-1304

Kreymann B, Ghatei MA, Burnet P, Williams G, Kanse S, Diani AR \& Bloom SR (1989) Characterization of glucagon-like peptide-1(7-36)amide in the hypothalamus. Brain Res 502, 325-331.

Mattson MP, Perry T \& Greig N (2003) Learning from the gut. Nat Med 9 1113-1114

Miyawaki K, Yamada Y \& Yano H, et al. (1999) Glucose intolerance caused by a defect in the entero-insular axis: a study in gastric inhibitory polypeptide receptor knockout mice. Proc Natl Acad Sci USA 96, $14843-14847$.

Mojsov S, Weir GC \& Habener JF (1987) Insulinotropin: glucagon-like peptide I (7-37) co-encoded in the glucagon gene is a potent stimulator of insulin release in the perfused rat pancreas. J Clin Invest 79, 616-619.

Moody A, Thim L \& Valverde I (1984) The isolation and sequencing of human gastric inhibitory polypeptide (GIP). FEBS Lett 172, $142-148$.

Moore B, Edie E \& Abram J (1906) On the treatment of diabetes mellitus by acid extract of duodenal mucous membrane. Biochem $J$ 1, 28-38.

Moore MC \& Cherrington AD (1996) The nerves, the liver, and the route of feeding: an integrated response to nutrient delivery. Nutrition 12, 282-284.

Moore MC, Rossetti L, Pagliassotti MJ, Monahan M, Venable C, Neal D \& Cherrington AD (1996) Neural and pancreatic influences on net hepatic glucose uptake and glycogen synthesis. Am J Physiol 271, E215-E222.

Nakabayashi H, Nishizawa M, Nakagawa A, Takeda R \& Niijima A (1996) Vagal hepatopancreatic reflex effect evoked by intraportal appearance of tGLP-1. Am J Physiol 271, E808-E813.

Nathan D, Schreiber E, Fogel H, Mojsov S \& Habener J (1991) Insulinotropic action of glucagon like peptide-1-(7-37) in diabetic and non diabetic subjects. Diabetes Care 15, 270-275.

Nauck M (1996) Therapeutic potential of glucagon-like peptide 1 in type 2 diabetes. Diabet Med 13, S39-S43.

Nauck MA (1998) Glucagon like peptide 1 (GLP-1): a potent gut hormone with a possible therapeutic perspective. Acta Diabetol 35, $117-129$.

Nauck MA, Bartels E, Orskov C, Ebert R \& Creutzfeldt W (1993a) Additive insulinotropic effects of exogenous synthetic human gastric inhibitory polypeptide and glucagon-like peptide-1-(7-36) amide infused at near-physiological insulinotropic hormone and glucose concentrations. J Clin Endocrinol Metab 76, 912-917.

Nauck MA, Heimesaat MM, Orskov C, Holst JJ, Ebert R \& Creutzfeldt W (1993b) Preserved incretin activity of glucagon-like peptide 1 [7-36 amide] but not of synthetic human gastric inhibitory polypeptide in patients with type-2 diabetes mellitus. J Clin Invest 91, 301-307.

Nauck MA, Kleine N, Orskov C, Holst JJ, Willms B \& Creutzfeldt W (1993c) Normalization of fasting hyperglycaemia by exogenous glucagon-like peptide 1 (7-36 amide) in type 2 (non-insulin-dependent) diabetic patients. Diabetologia 36, 741-744.

Nauck MA, Siemsgluss J, Orskov C \& Holst JJ (1996) Release of glucagon-like peptide 1 (GLP-1 [7-36 amide]), gastric inhibitory polypeptide (GIP) and insulin in response to oral glucose after upper and lower intestinal resections. Z Gastroenterol 34, 159-166.

Niijima A (1969) Afferent impulse discharges from glucoreceptors in the liver of the guinea pig. Ann NY Acad Sci 157, 690-700.

Niijima A (1985) Blood glucose levels modulate efferent activity in the vagal supply to the rat liver. $J$ Physiol 364, 105-112.

Nordt TK, Besenthal I, Eggstein M \& Jakober B (1991) Influence of breakfasts with different nutrient contents on glucose, $\mathrm{C}$ peptide, insulin, glucagon, triglycerides, and GIP in non-insulin-dependent diabetics. Am J Clin Nutr 53, 155-160.

Oomura Y (1981) Chemosensitive neuron in the hypothalamus related to food intake behavior. Jpn J Pharmacol 31, 1P-12P.

Oomura Y, Ono T, Ooyama H \& Wayner MJ (1969) Glucose and osmosensitive neurones of the rat hypothalamus. Nature 222, 282-284.

Oomura Y, Ooyama H, Sugimori M, Nakamura T \& Yamada Y (1974) Glucose inhibition of the glucose-sensitive neurone in the rat lateral hypothalamus. Nature 247, 284-286.

Orskov C, Holst JJ, Poulsen SS \& Kirkegaard P (1987) Pancreatic and intestinal processing of proglucagon in man. Diabetologia 30, 874-881

Orskov C, Holst JJ \& Nielsen OV (1988) Effect of truncated glucagon-like peptide-1, proglucagon-(78-107) amide, on endocrine secretion from pig pancreas, antrum, and nonantral stomach. Endocrinology 123, 2009-2013.

Orskov C, Rabenhoj L, Wettergren A, Kofod H \& Holst JJ (1994) Tissue and plasma concentrations of amidated and glycine-extended glucagonlike peptide I in humans. Diabetes 43, 535-539.

Orskov C, Wettergren A \& Holst JJ (1996) Secretion of the incretin hormones glucagon-like peptide-1 and gastric inhibitory polypeptide correlates with insulin secretion in normal man throughout the day. Scand $J$ Gastroenterol 31, 665-670.

Pagliassotti MJ, Myers SR, Moore MC, Neal DW \& Cherrington AD (1991) Magnitude of negative arterial-portal glucose gradient alters net hepatic glucose balance in conscious dogs. Diabetes 40, 1659-1668.

Pagliassotti MJ, Holste LC, Moore MC, Neal DW \& Cherrington AD (1996) Comparison of the time courses of insulin and the portal signal on hepatic glucose and glycogen metabolism in the conscious dog. J Clin Invest 97, 81-91.

Perley M \& Kpnis D (1967) Plasma insulin responses to oral and intravenous glucose: studies in normal and diabetic subjects. $J$ Clin Invest $\mathbf{4 6}$, 1954-1962.

Plaisancie P, Dumoulin V, Chayvialle JA \& Cuber JC (1995) Luminal glucagon-like peptide-1(7-36) amide-releasing factors in the isolated vascularly perfused rat colon. $J$ Endocrinol 145, 521-526.

Plant TM \& Durrant AR (1997) Circulating leptin does not appear to provide a signal for triggering the initiation of puberty in the male rhesus monkey (Macaca mulatta). Endocrinology 138, 4505-4508.

Qualmann C, Nauck MA, Holst JJ, Orskov C \& Creutzfeldt W (1995) Insulinotropic actions of intravenous glucagon-like peptide-1 (GLP-1) [7-36 amide] in the fasting state in healthy subjects. Acta Diabetol 32, 13-16.

Reimer RA \& McBurney MI (1996) Dietary fiber modulates intestinal proglucagon messenger ribonucleic acid and postprandial secretion of glucagon-like peptide-1 and insulin in rats. Endocrinology 137, 3948-3956 
Ritzel U, Fromme A, Ottleben M, Leonhardt U \& Ramadori G (1997) Release of glucagon-like peptide-1 (GLP-1) by carbohydrates in the perfused rat ileum. Acta Diabetol 34, 18-21.

Rizza R, Cryer P \& Gerich J (1979) Role of glucagon, catecholamines, and growth hormone in human glucose counterregulation: effects of somatostatin and combined alpha and beta adrenergic blockade on plasma glucose recovery and glucose flux rates following insulininduced hypoglycemia. J Clin Invest 64, 62-71.

Roberge J, Gronau K \& Brubaker P (1996) Gastrin-releasing peptide is a novel mediator of proximal nutrient-induced proglucagon-derived peptide secretion from the distal gut. Endocrinology 137, 2383-2388.

Rocca AS \& Brubaker PL (1995) Stereospecific effects of fatty acids on proglucagon-derived peptide secretion in fetal rat intestinal cultures. Endocrinology 136, 5593-5599.

Rocca AS \& Brubaker PL (1999) Role of vagus nerve in mediating proximal nutrient induced glucagon like peptide-1 secretion. Endocrinology 140, 1687-1694.

Rodriquez de Fonseca F, Navarro M \& Alvarez E, et al. (2000) Peripheral versus central effects of glucagon-like peptide-1 receptor agonists on satiety and body weight loss in Zucker obese rats. Metabolism 49, 709-717.

Rouille Y, Westermark G, Martin SK \& Steiner DF (1994) Proglucagon is processed to glucagon by prohormone convertase PC2 in alpha TC1-6 cells. Proc Natl Acad Sci USA 91, 3242-3246.

Rouille Y, Martin S \& Steiner DF (1995) Differential processing of proglucagon by the subtilisin-like prohormone convertases PC2 and PC3 to generate either glucagon or glucagon-like peptide. J Biol Chem 270, 26488-26496.

Schirra J, Katschinski M, Weidmann C, Schafer T, Wank U, Arnold R \& Goke B (1996) Gastric emptying and release of incretin hormones after glucose ingestion in humans. J Clin Invest 97, 92-103.

Schmitt M (1973) Influence of hepatic portal receptors on hypothalamic feeding and satiety centers. Am J Physiol 225, 1089-1095.

Scrocchi LA, Brown TJ, MaClusky N, Brubaker PL, Auerbach AB, Joyner AL \& Drucker DJ (1996) Glucose intolerance but normal satiety in mice with a null mutation in the glucagon-like peptide 1 receptor gene. Nat Med 2, 1254-1258.

Shima K, Hirota M \& Ohboshi C (1988) Effect of glucagon-like peptide-1 on insulin secretion. Regul Pept 22, 245-252.

Shimizu I, Hirota M, Ohboshi C \& Shima K (1987) Identification and localization of glucagon-like peptide-1 and its receptor in rat brain. Endocrinology 121, 1076-1082.

Shimizu N, Oomura Y, Novin D, Grijalva CV \& Cooper PH (1983) Functional correlations between lateral hypothalamic glucose-sensitive neurons and hepatic portal glucose-sensitive units in rat. Brain Res $\mathbf{2 6 5}$, 49-54

Stumpel F \& Jungermann K (1997) Sensing by intrahepatic muscarinic nerves of a portal-arterial glucose concentration gradient as a signal for insulin-dependent glucose uptake in the perfused rat liver. FEBS Lett 406, 119-122.

Takeda J, Seino Y \& Tanaka K, et al. (1987) Sequence of an intestinal cDNA encoding human gastric inhibitory polypeptide precursor. Proc Natl Acad Sci USA 84, 7005-7008.

Tanizawa Y, Riggs AC, Elbein SC, Whelan A, Donis-Keller H \& Permutt MA (1994) Human glucagon-like peptide-1 receptor gene in NIDDM. Identification and use of simple sequence repeat polymorphisms in genetic analysis. Diabetes 43, 752-757.

Thiele TE, Van Dijk G, Campfield LA, Smith FJ, Burn P, Woods SC, Bernstein IL \& Seeley RJ (1997) Central infusion of GLP-1, but not leptin, produces conditioned taste aversions in rats. Am J Physiol 272, R726-R730.

Thorens B \& Waeber G (1993) Glucagon-like peptide-I and the control of insulin secretion in the normal state and in NIDDM. Diabetes $\mathbf{4 2}$, 1219-1225.

Thorens B, Porret A, Buhler L, Deng SP, Morel P \& Widmann C (1993)
Cloning and functional expression of the human islet GLP-1 receptor. Demonstration that exendin-4 is an agonist and exendin-(9-39) an antagonist of the receptor. Diabetes 42, 1678-1682.

Tseng CC, Zhang XY \& Wolfe MM (1999) Effect of GIP and GLP-1 antagonists on insulin release in the rat. Am $J$ Physiol 276, E1049-E1054.

Turton MD, O'Shea D \& Gunn I, et al. (1996) A role for glucagon-like peptide-1 in the central regulation of feeding. Nature 379, 69-72.

Uttenthal LO, Toledano A \& Blazquez E (1992) Autoradiographic localization of receptors for glucagon-like peptide-1 (7-36) amide in rat brain. Neuropeptides 21, 143-146.

Vaag AA, Holst JJ, Volund A \& Beck-Nielsen HB (1996) Gut incretin hormones in identical twins discordant for non-insulin-dependent diabetes mellitus (NIDDM) - evidence for decreased glucagon-like peptide 1 secretion during oral glucose ingestion in NIDDM twins. Eur J Endocrinol 135, 425-432.

van Dijk G \& Thiele TE (1999) Glucagon-like peptide-1 (7-36) amide: a central regulator of satiety and interoceptive stress. Neuropeptides $\mathbf{3 3}$, 406-414.

van Eyll B, Lankat-Buttgereit B, Bode HP, Goke R \& Goke B (1994) Signal transduction of the GLP-1-receptor cloned from a human insulinoma. FEBS Lett 348, 7-13.

Volz A, Goke R, Lankat-Buttgereit B, Fehmann HC, Bode HP \& Goke B (1995) Molecular cloning, functional expression, and signal transduction of the GIP-receptor cloned from a human insulinoma. FEBS Lett 373, 23-29.

Wang Z, Wang RM, Owji AA, Smith DM, Ghatei MA \& Bloom SR (1995) Glucagon-like peptide-1 is a physiological incretin in rat. $J$ Clin Invest 95, 417-421.

Wei Y \& Mojsov S (1995) Tissue-specific expression of the human receptor for glucagon-like peptide-I: brain, heart and pancreatic forms have the same deduced amino acid sequences. FEBS Lett 358, 219-224.

Wettergren A, Wojdemann M, Meisner S, Stadil F \& Holst JJ (1997) The inhibitory effect of glucagon-like peptide-1 (GLP-1) 7-36 amide on gastric acid secretion in humans depends on an intact vagal innervation. Gut 40, 597-601.

Widmann C, Burki E, Dolci W \& Thorens B (1994) Signal transduction by the cloned glucagon-like peptide-1 receptor: comparison with signaling by the endogenous receptors of beta cell lines. Mol Pharmacol 45, 1029-1035.

Willms B, Werner J, Holst JJ, Orskov C, Creutzfeldt W \& Nauck MA (1996) Gastric emptying, glucose responses, and insulin secretion after a liquid test meal: effects of exogenous glucagon-like peptide-1 (GLP-1)-(7-36) amide in type 2 (noninsulin-dependent) diabetic patients. J Clin Endocrinol Metab 81, 327-332.

Yoshimoto S, Hirota M, Ohboshi C \& Shima K (1989) Identification of glucagon-like peptide-1(7-36) amide in rat brain. Ann Clin Biochem 26, 169-171.

Young AA, Gedulin BR \& Rink TJ (1996) Dose-responses for the slowing of gastric emptying in a rodent model by glucagon-like peptide (7-36) $\mathrm{NH} 2$, amylin, cholecystokinin, and other possible regulators of nutrient uptake. Metabolism 45, 1-3.

Zawalich WS \& Zawalich KC (1996) Glucagon-like peptide-1 stimulates insulin secretion but not phosphoinositide hydrolysis from islets desensitized by prior exposure to high glucose or the muscarinic agonist carbachol. Metabolism 45, 273-278.

Zawalich WS, Zawalich KC \& Rasmussen H (1993) Influence of glucagon-like peptide-1 on beta cell responsiveness. Regul Pept 44, 277-283.

Zhang Y, Cook JT, Hattersley AT, Firth R, Saker PJ, Warren-Perry M, Stoffel M \& Turner RC (1994) Non-linkage of the glucagon-like peptide 1 receptor gene with maturity onset diabetes of the young. Diabetologia 37, 721-724. 